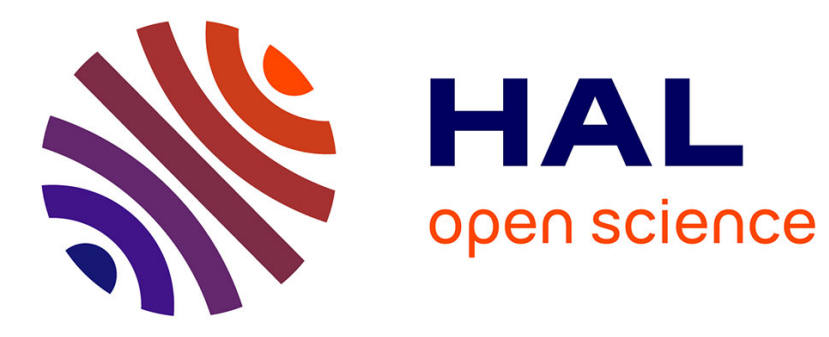

\title{
Demise of a harbor: a geochemical chronicle from Ephesus
}

Hugo Delile, Janne Blichert-Toft, Jean-Philippe Goiran, Friederike Stock, Florent Arnaud-Godet, Jean-Paul Bravard, Helmut Brückner, Francis Albarède

\section{To cite this version:}

Hugo Delile, Janne Blichert-Toft, Jean-Philippe Goiran, Friederike Stock, Florent Arnaud-Godet, et al.. Demise of a harbor: a geochemical chronicle from Ephesus. Journal of Archaeological Science, 2015, 53, pp.202-213. 10.1016/j.jas.2014.10.002 . halshs-01099871

\section{HAL Id: halshs-01099871 https://shs.hal.science/halshs-01099871}

Submitted on 7 Jan 2015

HAL is a multi-disciplinary open access archive for the deposit and dissemination of scientific research documents, whether they are published or not. The documents may come from teaching and research institutions in France or abroad, or from public or private research centers.
L'archive ouverte pluridisciplinaire HAL, est destinée au dépôt et à la diffusion de documents scientifiques de niveau recherche, publiés ou non, émanant des établissements d'enseignement et de recherche français ou étrangers, des laboratoires publics ou privés. 


\title{
Demise of a harbor: a geochemical chronicle from Ephesus
}

\author{
Hugo Delile ${ }^{\mathrm{a}, \mathrm{b}, *}$, Janne Blichert-Toft ${ }^{\mathrm{b}, \mathrm{c}}$, Jean-Philippe Goiran ${ }^{\mathrm{d}}$, Friederike Stock ${ }^{\mathrm{e}}$, \\ Florent Arnaud-Godet ${ }^{\mathrm{b}}$, Jean-Paul Bravard ${ }^{\mathrm{a}}$, Helmut Brückner ${ }^{\mathrm{e}}$, Francis Albarède ${ }^{\mathrm{b}, \mathrm{c}}$ \\ a Université Lumière Lyon 2, CNRS UMR 5600, 69676 Bron, France \\ ${ }^{\mathrm{b}}$ Ecole Normale Supérieure de Lyon, Université Claude Bernard-Lyon 1, CNRS UMR 5276, 69364 Lyon Cedex 7, France \\ ${ }^{\mathrm{c}}$ Department of Earth Science, Rice University, Houston, TX 77005, USA \\ d Maison de l'Orient et de la Méditerranée, CNRS UMR 5133, 69365 Lyon Cedex 7, France \\ e Institute of Geography, University of Cologne, Albertus-Magnus-Platz, 50923 Cologne (Köln), Germany
}

\section{A R T I C L E I N F O}

\section{Article history:}

Received 14 July 2014

Received in revised form

29 September 2014

Accepted 2 October 2014

Available online 12 October 2014

\section{Keywords:}

Harbor geoarcheology

Geochemistry

$\mathrm{Pb}$ isotopes

Roman age

Paleo-pollution

Ephesus

Küçük Menderes

\begin{abstract}
A B S T R A C T
At the end of the first century $\mathrm{BC}$, Ephesus became the Roman capital of Asia Minor and the most important commercial, religious, and cultural center of the region. In order to evaluate the status of anthropogenic fluxes in the port of Ephesus, a $12 \mathrm{~m}$ long sediment core drilled in the Roman basin was investigated to shed light on the paleo-environmental evolution of the harbor using grain size distribution analysis, ${ }^{14} \mathrm{C}$ ages, major and trace element geochemistry, and $\mathrm{Pb}$ isotope compositions. With the help of complementary sedimentological data and Principal Component Analysis, five distinct units were identified which, together, reflect the different stages of water history in the harbor. Among the major disruptive events affecting the port were earthquakes and military events, both of which were particularly effective at destroying the water distribution system.

Seasonal floods of the Cayster River (Küçük Menderes) were the major source of the silt that progressively infilled the harbor. Silting in was further enhanced by the westward migration of the river mouth. A single major disruptive event located at $550 \mathrm{~cm}$ core depth and heralding the development of anoxia in the harbor marks the end of the dynamic regime that otherwise controlled the harbor water throughout the Roman Empire period. This remarkable event may correspond to a major disruption of the aqueduct system or to a brutal avulsion of the Cayster River bed. It clearly represents a major disturbance in the history of life at Ephesus. It is poorly dated, but probably occurred during the reign of Augustus or shortly after. Lead isotope and trace metal evidence suggest that in the four bottom units pollution was subdued with respect to other $\mathrm{Pb}$ metal inputs, presumably those from aqueducts and natural karstic springs. Near the top of the core, which coincides with harbor abandonment and the more recent period, anthropogenic $\mathrm{Pb}$ contamination is clearly visible in both $\mathrm{Pb}$ abundances and isotopic compositions.
\end{abstract}

() 2014 Elsevier Ltd. All rights reserved.

\section{Introduction}

Lead isotope studies have opened up a new, though somewhat controversial, perspective on the development of the manufacturing status of ancient cultures over the past several millennia (Hong et al., 1994). Isolated artifacts alone do not suffice to assess the broad and long-lasting aspects of antique trade routes. Lead isotopes constitute a complementary tool in that they play a critical role wherever their compositions can be ascribed to anthropogenic influence in the form of lead and heavy metal

\footnotetext{
* Corresponding author. Université Lumière Lyon 2, CNRS UMR 5600, 69676 Bron, France. Tel.: +33682736653.

E-mail address: hdelile@gmail.com (H. Delile).
}

pollution of sediments accumulated in harbors, which are highly efficient traps for clays and suspensions. Anthropogenic impact using $\mathrm{Pb}$ isotopes as a tracer has so far been documented for the ancient harbors of Alexandria (Véron et al., 2006, 2013; Stanley et al., 2007), Sidon (Le Roux et al., 2003), Marseilles (Le Roux et al., 2005), and Rome (Delile et al., 2014a).

Applying similar methods to the Roman harbor of Ephesus is appealing because of the status of the Ephesus city port during Roman times as an exceptionally influential commercial and religious center of the ancient Mediterranean world. Ephesus was a major town of Asia Minor and has a long history that began in the 10th century BC. Its position at short distances from both the Dardanelles and the populated city states of southern Greece gave Ephesus a strategic role in all the wars affecting Asia Minor and the Aegean Sea since the Persian wars of the classical period. Its 
importance remained prominent during Hellenistic and Roman times and during the entire history of the Byzantine Empire, and only declined as a result of the Turkish conquest. Because sediments gradually filled in the inlet of the Cayster River (Küçük Menderes), the harbor of Ephesus repeatedly moved down river over the centuries (Kraft et al., 2000, 2011).

Here we use samples from a $12 \mathrm{~m}$ long sediment core taken in the Roman port of Ephesus to investigate the paleo-environmental and hydraulic evolution of the harbor using grain size distribution analysis, ${ }^{14} \mathrm{C}$ ages, major and trace element geochemistry, and $\mathrm{Pb}$ isotope compositions. We focus in particular on the relative abundances of $\mathrm{Pb}$ and other chalcophile elements in the harbor sediments and discuss the respective status of the anthropogenic and natural metal fluxes and their origins as deduced from the $\mathrm{Pb}$ isotope record.

\section{Historical background}

Literature on the history of Ephesus is abundant because of the wealth of ruins left by its different inhabiting cultures and its role in the history of this part of the world first as a major religious center dedicated to Artemis and later as one of the leading churches of the Mediterranean world. For a detailed historical context of the present work, the reader is referred to the well-documented textbook by Foss (1979) and to Scherrer (1995). Here we provide only a brief overview.

Different sites were inhabited in the immediate vicinity of classical Ephesus since the Neolithic culture and during the Bronze Age. The historical city (close to the Artemision) was founded in the 10th century BC by Ionians and became part of the Ionian League. The classic site (at the base of the western side of the Panayırdağ) was occupied around 300 BC under Lysimachus, one of Alexander's generals, but quickly passed under Seleucid and then Ptolemaic rules. After the Battle of Magnesia in 190 BC, Ephesus came under the domination of Pergamon, and finally became part of the Roman Republic in 133 BC. After the Mithridatic wars (ending in 63 BC), Augustus made Ephesus the capital of Asia Minor. At that stage, the surface area of the city, enclosed by the walls of Lysimachus, is thought to have extended over more than $2 \mathrm{~km}^{2}$ and its population to have reached 50,000 inhabitants.

The city and its temple were destroyed by the Goths in $262 \mathrm{AD}$. But Ephesus was rebuilt and enlarged by Constantine and soon recaptured most of the importance it had held since Hellenistic times. A burst of seismic activity between 358 and 365 AD repeatedly destroyed major cities around the Aegean (Guidoboni, 1994), including Ephesus. In the 7th century AD, several additional disasters struck Ephesus, notably the major earthquake of 614 AD, as well as the repeated sacks by Arab, Frankish, and Turkish raiders. Western Turkey is well known for being subjected to frequent earthquakes of large magnitude (e.g., Vannucci et al. 2004). Although some dates are not well established, particularly severe earthquakes persistently ravaged the city in AD 17, 23, 47, 178, 194, 262, 275, 337, 358 to 365, and 614 (Guidoboni, 1994; Foss, 1979). In AD 1304, what was by then left of Ephesus fell into the hands of the Turks, and its population was either deported or massacred. These adverse troubles combined with the final stages of insilting of the harbor basin, which had incessantly plagued harbor activity since its early Hellenistic days (Strabo, XIV.1.24), precipitated the demise of the harbor and the city it served.

\section{The study area}

Ephesus' harbor lies on the Aegean coast of Turkey at the western extremity of the Küçük Menderes graben (KMG) (Fig. 1). The KMG corresponds to the catchment area of the Küçük Menderes (Cayster) river, which is divided into five sub-basins delimited by pre-Miocene geology (Rojay et al., 2005). The surrounding hills are composed of crystalline marble or partially dolomitic breccias of Mesozoic age (Vetters, 1989; Çakmakoğlu, 2007). The hills over which Ephesus aqueducts run also include Paleozoic crystalline rocks such as granites, gneisses, and micaschists. Water was brought to the city by up to seven aqueducts built between Archaic times and the Roman Empire and repaired during different periods, notably after major earthquakes. This point is particularly important since all the waters from the aqueducts terminated in the harbor where they were susceptible to mixing with Cayster river water, marine water, and waste waters of public (baths, fountains) and domestic usage, as well as with water from local workshops (Ortloff and Crouch, 2001).

The variation of relative sea level and the westward migration of the shoreline since Antiquity have been studied by Brückner (2005) and Pavlopoulos et al. (2012). Comparison of the apparent sea level changes with the values predicted by the regional model of Lambeck and Purcell (2005) indicates that subsidence of the coastline next to Ephesus since the classical period was of the order of 3-7 m. According to coring evidence and with respect to sea level index points it seems that, in addition to eustatic sea level rise, there are max. $2 \mathrm{~m}$ of rise caused by subsidence.

Geoarcheological research has been carried out at the Ephesus site and in the delta of the Cayster river since the 1990s (Brückner, 1997, 2005; Kraft et al., 1999, 2000, 2001, 2011; Stock et al., 2013, 2014, unpublished data). Besides reconstruction of the successive paleo-environments and the coastline as it has existed since 6000-5000 BC (Fig. 1), this work also has shown that delta progradation led to multiple westward resettlements of the harbor. The ceaseless fight against silting to maintain the harbor of Ephesus as a functioning port during the Hellenistic period is first and foremost reflected in the displacement of the city to the western side of mount Pion (Panayırdağ) by Lysimachus in 290 BC (Scherrer, 1995).

\section{Analytical techniques}

A sediment core about $12 \mathrm{~m}$ long (EPH 276) was drilled in the hexagonal Roman harbor basin of Ephesus (Fig. 1). We sampled the core at high resolution by taking a total of 111 samples (one sample every $10 \mathrm{~cm}$ ). The samples were analyzed for grain size distributions (see Stock et al., 2013, for details), major and trace element concentrations (Table S1; see Delile et al., 2014b, for details), and Pb isotope compositions (Table S2; see here below and Delile et al., 2014a, for details). Lead isotope compositions were obtained not on the bulk sediment, but, in order to isolate potential anthropogenic components, on $\mathrm{HBr}$ leachates. The leaching procedure consisted in first treating the samples with chloroform to remove most of the organic fraction, then, after rinsing the residues with clean water, leaching them with dilute $\mathrm{HBr}$ including ultrasonicating and heating steps. As shown for Portus (Delile et al., 2014a), this technique enhances the contrast between $\mathrm{Pb}$ held in surface contamination-prone coatings and detrital silicates. Carbonates also dissolve during the leaching process, but $\mathrm{Pb}$ contents of detrital carbonates are naturally low. As for carbonates precipitated within the harbor, they are of biogenic origin (cf. discussion of series $\mathrm{D}$ and $\mathrm{E}$ below) likely meaning that isotope information obtained on carbonate-rich samples is consistent with that derived from the leachates of the rest of the sample series. The $\mathrm{HBr}$ leach fraction was recovered for $\mathrm{Pb}$ separation by anion-exchange chromatography using $\mathrm{HBr}$ as eluent of the sample matrix and $\mathrm{HCl}$ as eluent of the $\mathrm{Pb}$. Lead was also separated from the residues of 16 of the 111 EPH 276 samples. The amounts of $\mathrm{Pb}$ extracted from all samples were large $(>1 \mu \mathrm{g})$ and orders of magnitude above the total procedural blank of $\sim 20 \mathrm{pg}$. The purified $\mathrm{Pb}$ was analyzed for its isotopic composition by multiple-collector inductively coupled plasma mass spectrometry 


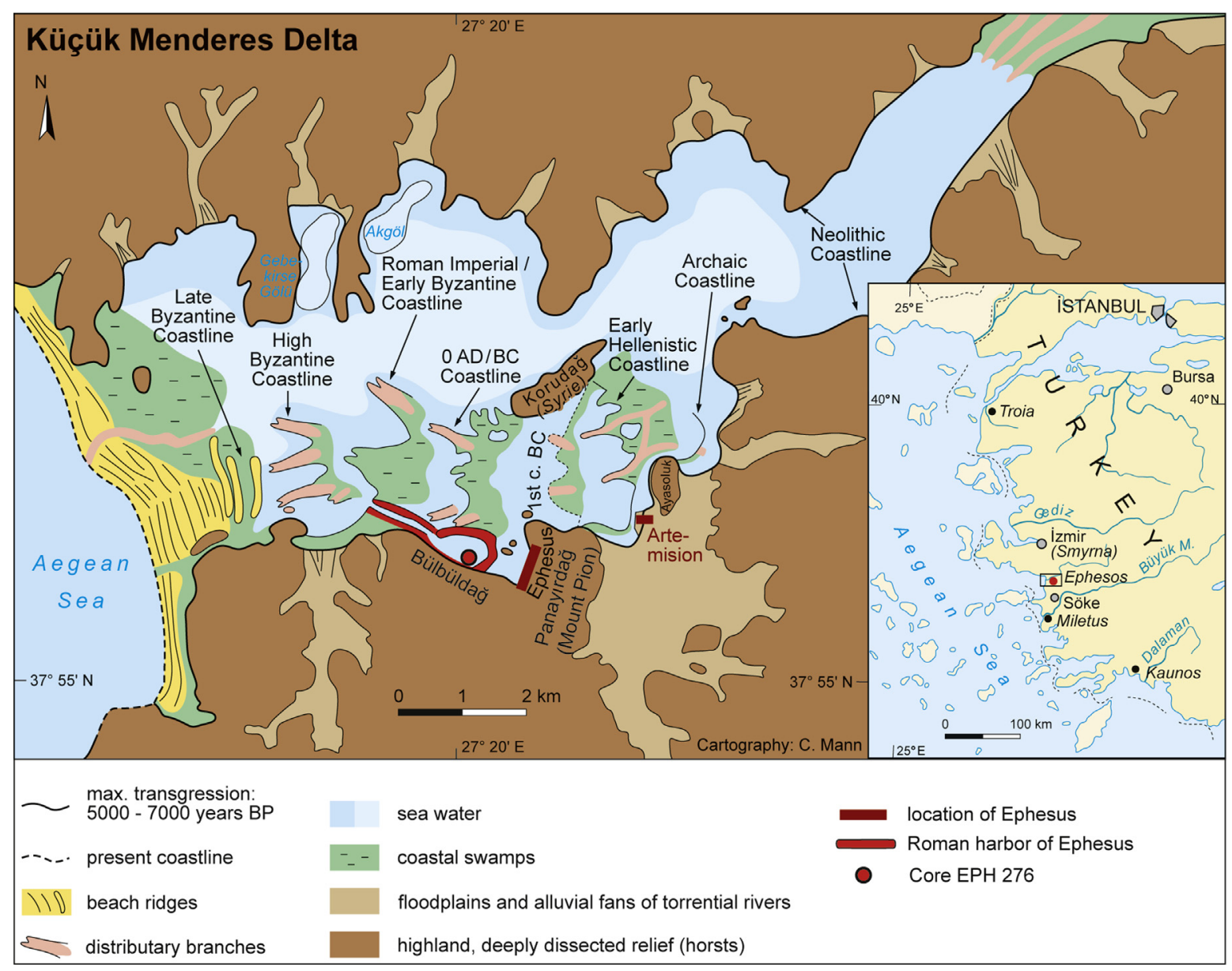

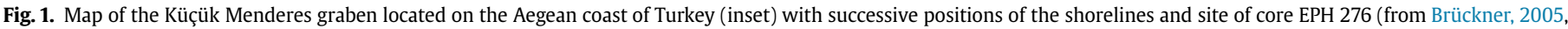
modified by Stock et al., 2013 and this study).

(Nu Plasma $500 \mathrm{HR}$ ) at ENS Lyon using Tl for instrumental mass bias correction and bracketing the samples with the NIST 981 standard for which the values of Eisele et al. (2003) were used.

Six samples were AMS- ${ }^{14} \mathrm{C}$-dated (Table S3), complementing the chronostratigraphy of neighboring cores analyzed by Stock et al. (unpublished data). The Carbon-14 ages were obtained on fragments of wood, vegetal matter, seeds, and pollen, and are listed in Table S3 and shown in Figs. 2 and 3. Errors on raw radiocarbon ages $\mathrm{BP}$ are reported at the 95 percent confidence level (two sigma). The measured ${ }^{14} \mathrm{C}(\mathrm{BP})$ ages were converted into $\mathrm{BC}-\mathrm{AD}$ dates relative to the continental and marine curves of Reimer et al. (2009) using the Clam software (Blaauw, 2010).

Interpretation of the analytical results rests on different methods of data processing. We applied Principal Component Analysis (PCA) and Factor Analysis to major and trace element concentration data, as well as loss-on-ignition (L.O.I.) (Fig. 2). In the very large data sets typical of those that modern geochemistry can now produce, observations are often correlated. A common case is that of the dilution of elements in sediments by detrital quartz. Such effects render the reading of the underlying causes of geochemical variation and their number difficult. PCA consists in rotating the data in their multidimensional space to convert them into uncorrelated variables known as principal components. Uncorrelated does not equate with independent, however, implying that small changes in rotation may affect all the principal components. PCA generally demonstrates that the variability of the observations can be accounted for by a very small (2-4) subset of variables that carry the bulk of the total variance. Principal components can be calculated from the covariance matrix or from the correlation matrix. Factor Analysis is a related technique that searches for the minimum variance for an arbitrary number of uncorrelated variables. It usually starts with PCA and implements different modes of rotation and weighing.

In addition to the PCA and Factor Analysis we also converted the $\mathrm{Pb}$ isotope compositions into their corresponding geochemically informed parameters, which are the model age $T_{\text {mod }}$ and the ${ }^{238} \mathrm{U} /{ }^{204} \mathrm{~Pb}(\mu)$ and $\mathrm{Th} / \mathrm{U}(\kappa)$ ratios (Table S2) using the equations given by Albarède et al. (2012), who also justified the advantages of this representation over those based on raw $\mathrm{Pb}$ isotope ratios. In short, $T_{\text {mod }}$ is a proxy for the tectonic age of crystalline rocks and their associated ore deposits (or depositional age for sediments), while $\mu$ is the ${ }^{238} \mathrm{U} /{ }^{204} \mathrm{~Pb}$ and $\kappa$ the Th/U ratio of the province in which these rocks formed. $T_{\text {mod }}$ closely maps the distribution of the Alpine, Hercynian, and early Paleozoic provinces of Europe, while $\mu$ delineates collision belts, and $\kappa$ is a geochemical parameter with a remarkable regional consistency related to uplift and erosion. Maps of these parameters can be used to divide Europe into coherent regions (Delile et al., 2014a), which justify the use of $T_{\bmod } \mu$, and $\kappa$ to determine provenance of archeological artifacts. $T_{\text {mod }} \mu$, and $\kappa$ in turn provide a rapid characterization of the geological environment in which ores formed. A Matlab code is given in Appendix A and an Excel spreadsheet in which to calculate these parameters will be provided upon request. As mentioned above, $T_{\text {mod }}$ represents the tectonic age of the geological province to which a given sample 


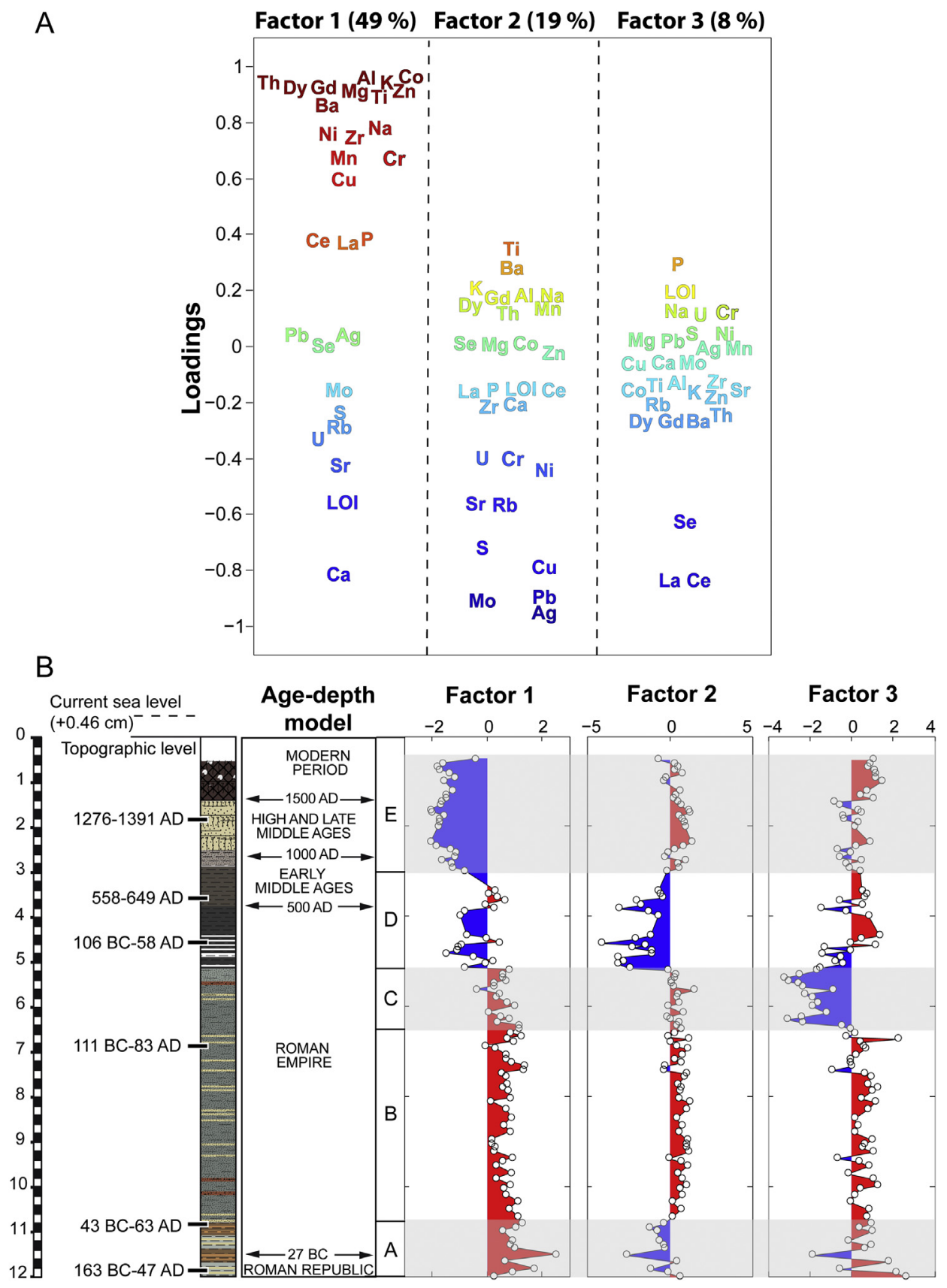

B

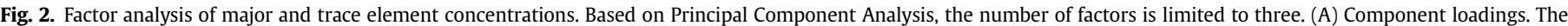

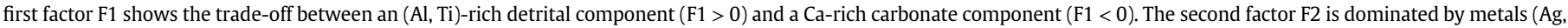

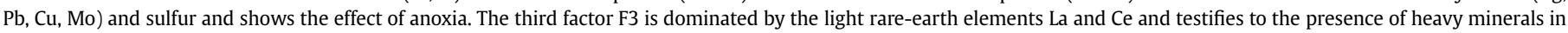
sand. (B) Distribution of the different factors with depth in the column. The plots are compared with the sedimentary units and the age-depth model.

belongs, while $\mu$ is best perceived as an indicator of whether this province is a collision range or a tectonically stable area. The variable $\kappa$ distinguishes upper crust with low $\kappa$ values from middle and lower crust with higher $\kappa$ values (Albarède et al., 2012). The precision and accuracy of $T_{\text {mod }}$ is typically of a few tens of Ma, but, occasionally, the $T_{\bmod }-\mu-\kappa$ model fails when the underlying closed-system assumption breaks down due to U addition by recent weathering or hydrothermal activity.

\section{Sedimentary units and the age-depth model}

The core has been divided into five different units labeled A, B, C, $\mathrm{D}$, and $\mathrm{E}$ on the basis of the sedimentological and geochemical traits described in Fig. 3A; they span the entire period of activity of the Hellenistic, Roman, and Byzantine harbor (Table 1).

Unit A (1200-1080 cm) exhibits alternating brown and gray varves composed of massive clayey silts with the presence of several beige to ocher fine layers. The C/M plot (Fig. 3B) indicates that the depositional processes are represented by mixed decantation and graded suspension. Units B and C $(1080-515 \mathrm{~cm})$ are characterized by gray to greenish massive sandy silts with the presence of several beige to ocher fine layers enriched in sand. These units were deposited as a graded suspension with embedded fine layers derived from mixed processes of graded and uniform suspension. Unit D $(515-290 \mathrm{~cm})$ consists of dark to greyish silts with variable clay (bottom) and sand (top) enrichments. From 
A

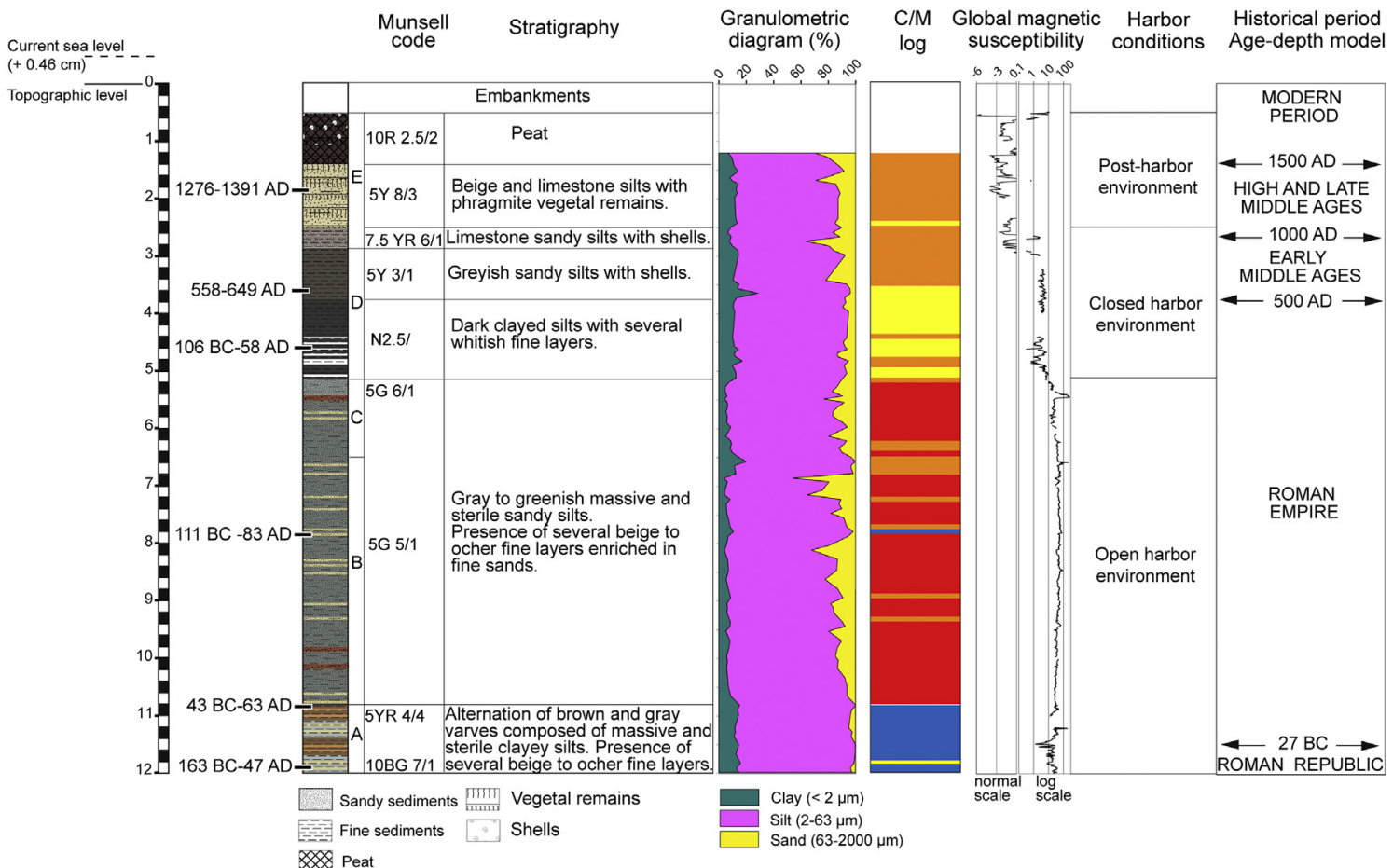

B

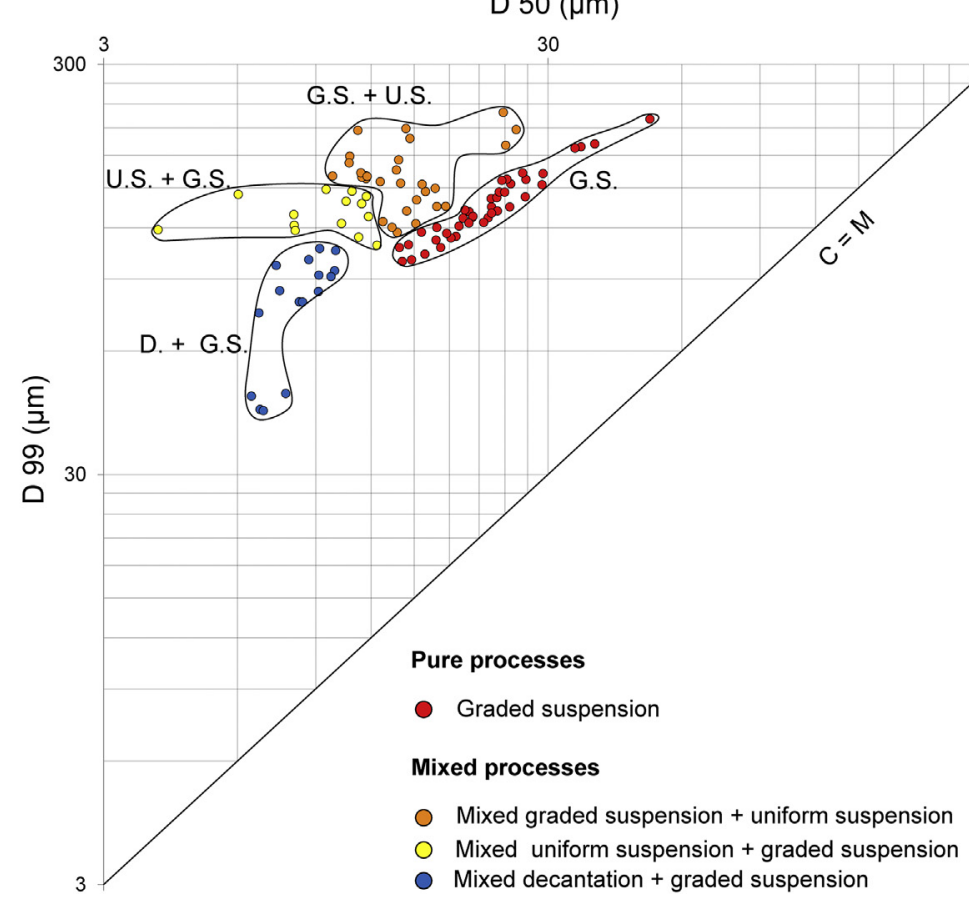

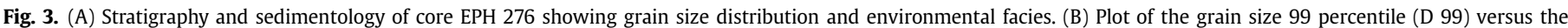

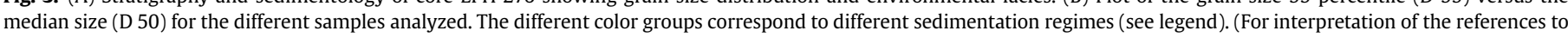
color in this figure legend, the reader is referred to the web version of this article.)

bottom to top, deposit processes evolve from mixed uniform and graded suspension to a blend with graded and uniform suspensions. Unit E $(<290 \mathrm{~cm})$ is composed of beige sandy silts with phragmite vegetal remains. The depositional processes point mostly to mixed graded and uniform suspensions.

The age-depth model is based on six ${ }^{14} \mathrm{C}$ ages (Fig. 4, Table S3). The four oldest ${ }^{14} \mathrm{C}$ ages fall within a narrow time interval and are statistically indistinguishable. An approximate seven meters of sediment were deposited in a few tens of years during the reign of Augustus or shortly after. Such an extraordinarily fast sedimentation rate is consistent with a periodogram analysis (e.g., Albarède, 1995) of the magnetic susceptibility record. The periodogram, which is the equivalent of a Fourier transform for unequally spaced data, identifies prominent periodic fluctuations in the targeted property, here the magnetic susceptibility. After removal of long-term variations (de-trending) by fitting a fourth-degree polynomial, the shortest 
Table 1

Depth range of the sedimentary units and probable age assignment.

\begin{tabular}{lcl}
\hline Unit & Depth $(\mathrm{cm})$ & Probable age \\
\hline A & $1200-1070$ & Roman Republic \\
B & $1070-650$ & Early Roman Empire \\
C & $650-515$ & Late Roman Empire \\
D & $515-300$ & Early Byzantine (4th-8th century) \\
E & $300-0$ & Late Byzantine and Turkish \\
\hline
\end{tabular}

values with significance level $P>0.95$ occur at 20 and $24 \mathrm{~cm}$ (Fig. 5). Longer wavelength peaks probably reflect climatic effects or are artifacts of de-trending. Assuming a seasonal cause for the observed susceptibility fluctuations therefore indicates a sedimentation rate of $\sim 20 \mathrm{~cm}$ per year, equivalent, over the $7 \mathrm{~m}$ of sediment with the oldest ${ }^{14} \mathrm{C}$ ages, to $\sim 35$ years of sedimentary history. In contrast, the average sedimentation rate between the top three ${ }^{14} \mathrm{C}$ samples (early and late Byzantine) is only $\sim 0.2 \mathrm{~cm} \mathrm{a}^{-1}$.

\section{Results and discussion}

\subsection{Harbor hydraulics}

In order to understand the hydraulic dynamics of the harbor, we first need to estimate its water capacity. The approximate dimensions taken from aerial photographs lead to a volume of $(500 \times 400 \times 5) \mathrm{m}^{3}=1.0 \times 10^{6} \mathrm{~m}^{3}$ (see also Kirbihler, 2013; Stock et al., unpublished data). We assume that most of the sedimentary layers were deposited during short seasonal flood events of the Cayster River, whereas water running into the harbor came from different potential sources: seawater, runoff, karstic springs, and aqueducts. Seawater and water from springs and aqueducts must have been largely clear of sedimentary particles. Karstic springs are common in the area around the modern Lake Kocagöz (Somay et al., 2008; Somay and Gemici, 2009), which today exists on the site of the ancient harbor basin. A seawater component is present in the water from all the lakes, including Lake Kocagöz (Somay et al., 2008; Somay and Gemici, 2009). Such a component attests to a contribution from spring waters contaminated by marine intrusions into the karst. As for other water inputs, Kraft et al (2007)

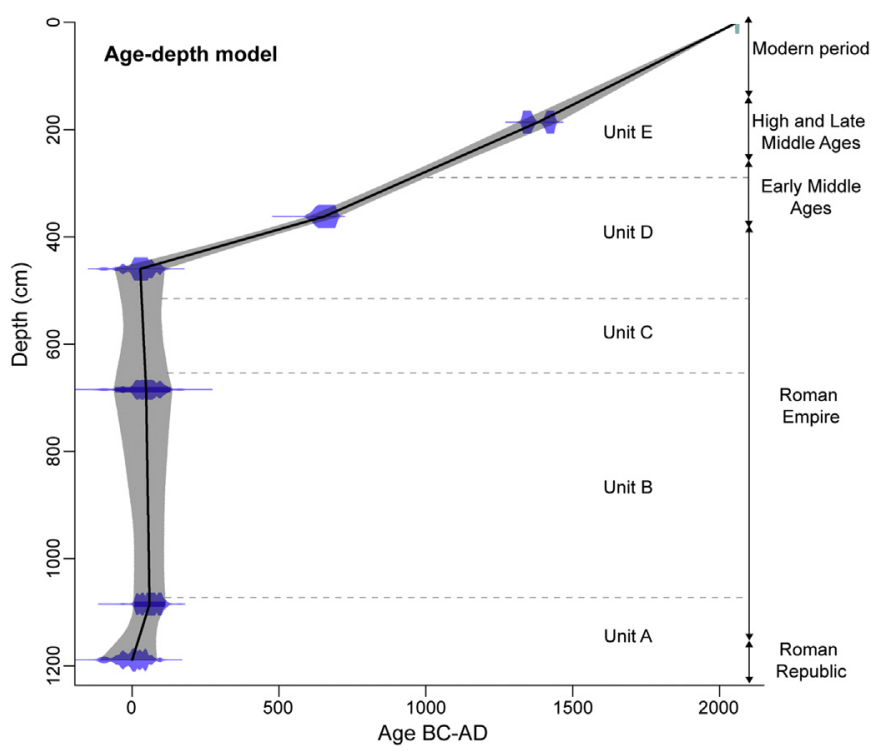

Fig. 4. Age-depth model for core EPH 276 deduced from the six ${ }^{14} \mathrm{C}$ dates with ranges calculated using the Clam software (Blaauw, 2010). The size of the data symbols reflects the confidence level. pointed out that all the city sewage was diverted into the Great Harbor.

The up to seven aqueducts built during the existence of the Ephesus port carried substantial volumes of water into the harbor. Wiplinger (2013) quotes an estimate of $0.6 \mathrm{~m}^{3} \mathrm{~s}^{-1}$ for the Derğirmendere aqueduct alone. Using the model by Ortloff and Crouch (2001), we surmise that the total water distribution to the city from the fully-functional aqueducts at the peak of city prosperity may have been over $\sim 2 \mathrm{~m}^{3} \mathrm{~s}^{-1}$. This number is substantial with respect to the mean discharge of $\sim 11.45 \mathrm{~m}^{3} \mathrm{~s}^{-1}$ inferred for the river, not including flood events (Vliegenthart et al., 2007), indicating that if other inputs such as karstic springs and runoff are disregarded, water in the harbor was replaced by the aqueducts in merely six days. This estimate is of course an average estimate and during seasonal droughts the ingress of seawater attested to by the presence of brackish fauna also contributed to the harbor's overall water budget.

Water output is difficult to constrain independently. The harbor canal, whose construction may have started as early as during the first century BC when the shoreline swept past the harbor, was narrow at the harbor entrance (Kraft et al., 2007). Assuming a crosssection at the narrowest point of $\sim 50 \mathrm{~m}^{2}$ would imply that aqueduct-delivered water was leaving the canal at a rate of $145 \mathrm{~m}$ per hour, probably fast enough to limit water ingress from the sea under fair weather conditions. This velocity must have been reduced by the effect of draught and evaporation during the dry (hot) season, and increased by local springs during the wet (cold) season. The presence of brackish water ostracods and occasional occurrence of marine foraminifera (Stock et al., unpublished data) demonstrate that the flow could occasionally be reversed, presumably as a result of a low water table and reduced precipitation during the dry season. Over time, the harbor was nevertheless affected by westward delta progradation and proximity to the mouth of the Cayster river (Fig. 1): by the end of the 2nd century BC, the delta had advanced as far as the Great Harbor (Kraft et al., 2007) and the canal had to be constructed, thus limiting ingress of seawater into the harbor basin even further.

To summarize harbor hydrodynamics, the 'normal' situation is that of a basin steadily filled by polluted urban water initially brought to the harbor by aqueducts and local springs and quickly evacuated through a canal with little ingress from the sea. As long as the coastline is not too distant, some seawater may be admitted during the dry season, while floods of, in the present case, the Cayster River dominated the water balance during spells of heavy rain. Silting in of the harbor would have been caused only by floods, which today are known to carry up to $100-150 \mathrm{~m}^{3} \mathrm{~s}^{-1}$ of water (Vliegenthart et al., 2007). The Romans went to great length to protect the harbor from river floods. Kraft et al. (2000, 2011) mention that, in the early 2nd century AD, Hadrian sought to divert the Cayster River with an $18 \mathrm{~m}$ high dam and also made multiple attempts to dredge the harbor.

\subsection{Environmental conditions in the harbor basin}

In order to assess the environmental conditions that prevailed during sedimentation, we plotted the concentrations of first-row transition elements (Ti-Zn) and other metallic elements $(\mathrm{Ga}, \mathrm{Pb}$, $\mathrm{Mo}, \mathrm{Bi}, \mathrm{Cd}, \mathrm{Ag}, \mathrm{As}$, and $\mathrm{Sb}$ ) normalized to the upper-crust concentrations of Rudnick and Gao (2003) (Fig. S1). Factor analysis of major and trace element abundances leads to the identification of three major components.

1. The first factor opposes elements indicative of the detrital load of the river $(\mathrm{Al}, \mathrm{Ti}, \mathrm{Mg}$, etc.) to those distinctive of carbonate minerals ( $\mathrm{Ca}, \mathrm{Sr})$ and L.O.I.

2. The second factor singles out chalcophile elements that, as attested to by the presence of sulfur in this group, precipitate as 


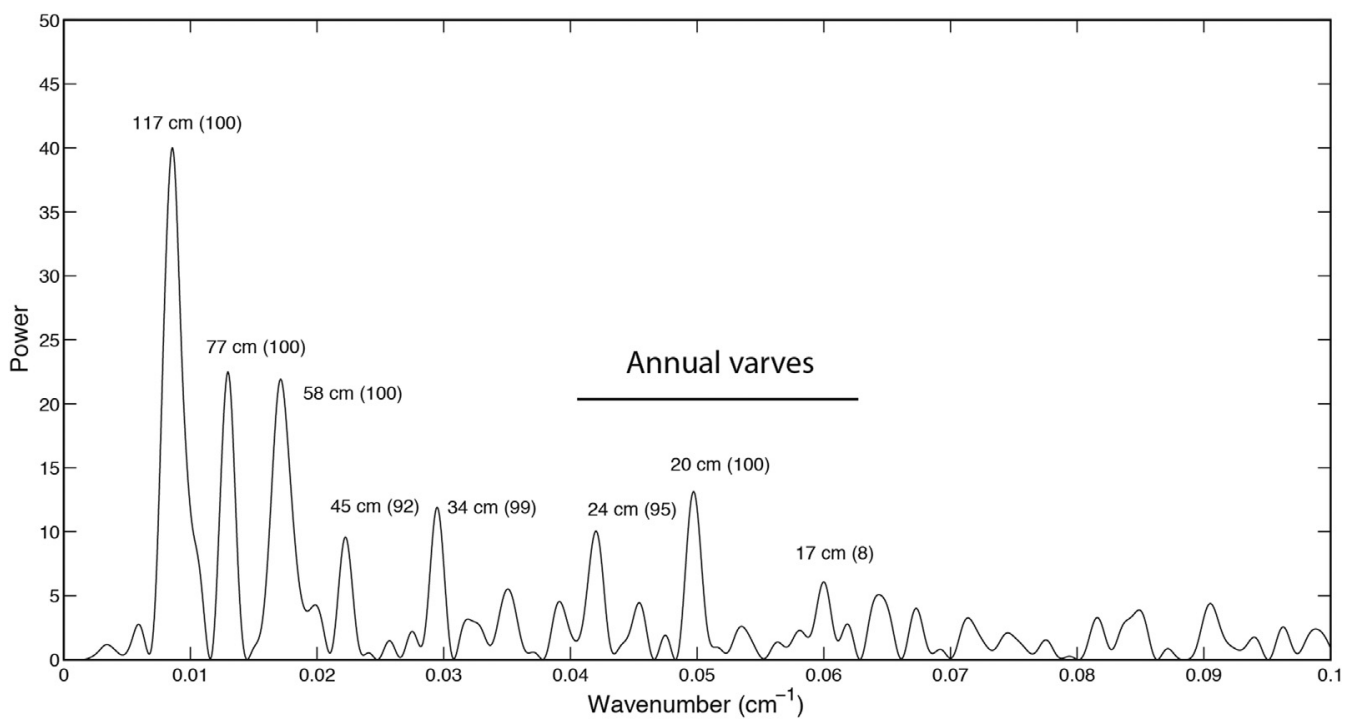

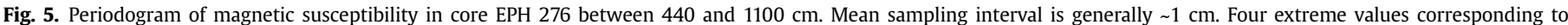

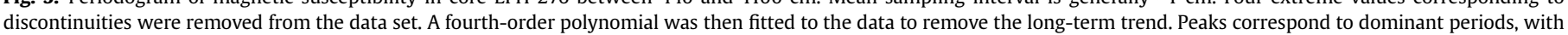

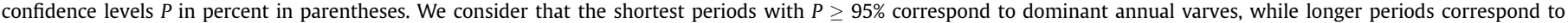
climatic effects or to de-trending artifacts. The periodogram is interpreted as indicating an average sedimentation rate of $20 \mathrm{~cm}$ per year.

sulfide under anoxic conditions ( $\mathrm{Pb}, \mathrm{Ag}, \mathrm{Cu}, \mathrm{Ni}, \mathrm{Mo})$, or are particularly sensitive to redox conditions $(\mathrm{U}, \mathrm{Cr})$. When the elements embedded in this factor are normalized to $\mathrm{Al}$ (Fig. 6), as a means of accounting for the variable abundance of the detrital component, and plotted against depth in the core, a sharp increase is observed at $520 \mathrm{~cm}$ depth. The significance of this factor deserves some discussion because $\mathrm{Pb}, \mathrm{Ag}$, and $\mathrm{Cu}$ may also be seen as representing an anthropogenic component. Fig. 6 and S1 further show the striking consistency of these metals both among themselves and with respect to sulfur. Such regular behavior is not supportive of random contamination by a particular metal, such as $\mathrm{Pb}$. The $\mathrm{Mo}-\mathrm{Pb}$ correlation is very strong ( $r=0.90$ excluding the top five samples likely contaminated by gasoline $\mathrm{Pb})$ as is the $\mathrm{Ag}-\mathrm{Pb}$ correlation $(r=0.95)$. This factor therefore reflects more on changing redox conditions in the harbor than on anthropogenic pollution.
3. The third factor is dominated by La, Ce and, to a lesser extent, Se. Most other loadings are very small, except possibly P. The weak negative correlation between excess $\mathrm{La}$ and $\mathrm{Ce}$ on the one hand and $P$ deficit on the other hand suggests the presence of nonphosphatic rare-earth minerals, such as allanite, notably in the coarse silts between 515 and $650 \mathrm{~cm}$.

The accumulation of so much sediment in a matter of decades requires an explanation, especially since the thickness of the newly deposited layers exceeds the water depth usually assumed for the harbor (4-6 m), even next to the mole (Stock et al., unpublished data). One factor clearly is the westward progradation of the shoreline past the harbor at about the time of fast sedimentation. F. Stock (personal communication) obtained a ${ }^{14} \mathrm{C}$ age of $44 \mathrm{BC}-\mathrm{AD} 52$ for the silting in of the harbor canal consistent with the present finding. The sharp geochemical discontinuities at 650 and $550 \mathrm{~m}$

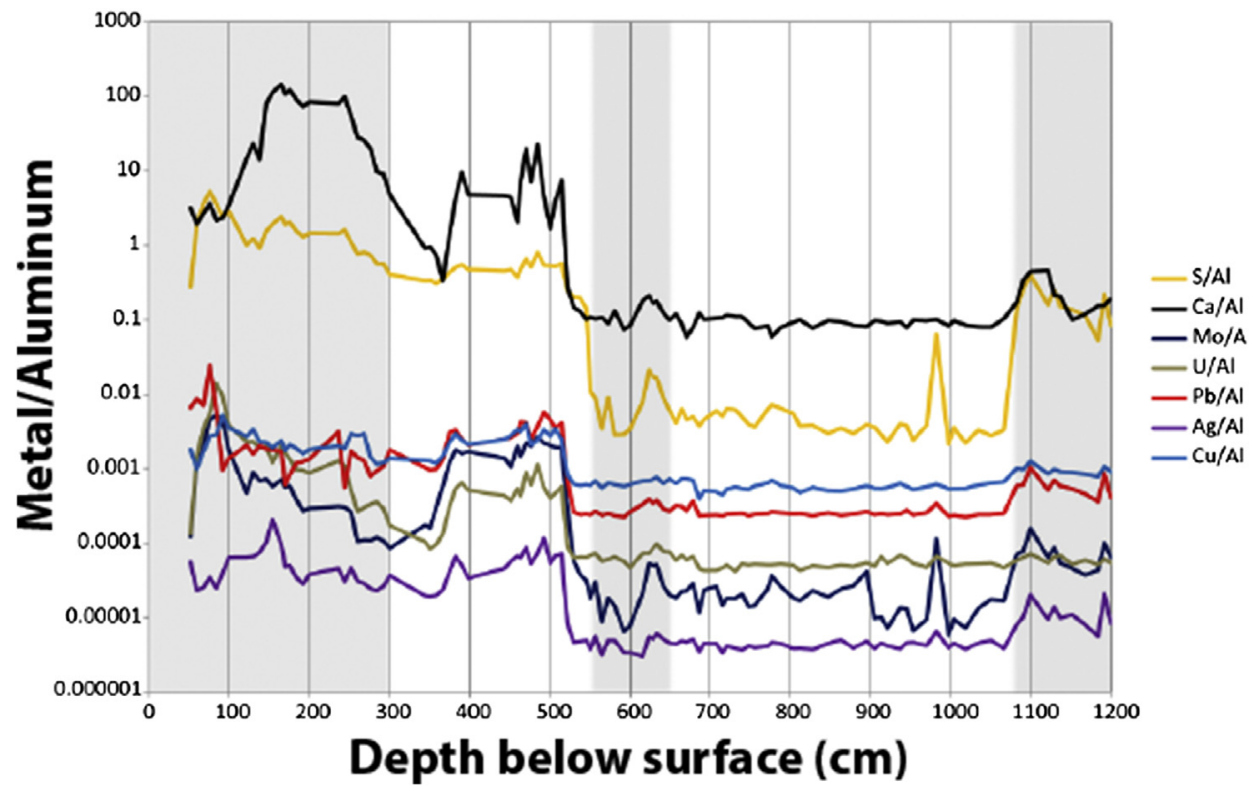

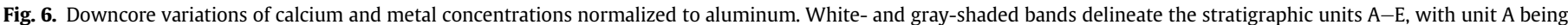
deepest and unit E shallowest. Note the discontinuities at $\sim 1080$ and $\sim 550 \mathrm{~cm}$ depth, notably the increase in $\mathrm{S}$ and chalcophile elements at the latter. 
are flagged by strong peaks of magnetic susceptibility (Fig. 3A). The efficiency of sediment confinement by the harbor prior to the three lowermost units is staggering, while the sudden drop in sedimentation rate and the short but intense episodes of high magnetic susceptibility require the intervention of a brutal event. A probable cause for this discontinuity is an abrupt jump of the Cayster River channel triggered by the abandonment of a meander (avulsions) or by exceptional floods (Brown, 1997). Co-seismic vertical movements (Pavlopoulos et al., 2012) associated with the major AD 17, 23 , and 47 earthquakes may also have played a role.

The lowermost unit A $(1200-1080 \mathrm{~cm})$ was deposited during the Roman Republic. It is consistently dominated by silt $(\mathrm{F} 1>0)$ with anoxic influence $(F 2<0)$. The anoxic conditions of the basin bottom as attested to by abundant S, Mo, and U (Fig. 2), small excesses of Mo and Ag (Fig. S1), and persistence of seasonal varves, indicate that the terrigenous flux into the early Roman harbor of Ephesus during the 1 st century $\mathrm{BC}$ was not noticeably oxidized whether water input was freshwater or seawater. Grain size distribution (Fig. 3) reflects an environment where decantation is important (Bravard and Peiry, 1999; Bravard et al., 2014). Input of oxygenated freshwater into the harbor, regardless of its source, therefore was limited and whatever water was added by the aqueduct system must have been dominated by sewage.

Unit B $(1080-650 \mathrm{~cm})$ continues to show the prevalence of the detrital flux $(\mathrm{F} 1>0)$, but now with evidence of oxygenation $(\mathrm{F} 2 \geq 0)$. The transition-element pattern typically is crustal in origin and no visible anomaly of Mo and Ag is observed (Fig. S1). Grainsize analysis indicates graded grain size distributions by turbulent waters, reflecting that, even at times of flood, water was being constantly evacuated from the harbor. Ephesus counted up to seven aqueducts implying that the early Roman harbor was saved from silting in as much by water from its many aqueducts continuously flushing the basin as by the Roman engineers. As shown by the return of some decantation events (Fig. 3), the aqueducts made silting depend on a fully functioning water distribution system. In this respect, the Menderes area is seismically active (Vannucci et al., 2004) and major earthquakes were particularly disruptive to the long and complex Ephesus aqueduct network (Passchier et al.,
2013). Reduction of the water input by the seismic destruction of aqueducts translates into reduced water egress from the harbor basin and hence enhanced efficiency of its role as a sediment trap. Silting in of the harbor in the aftermath of major earthquakes therefore became collateral damage to the rest of the disasters caused by the seismic activity.

The transition to unit $C$ (Fig. 2) $(650-550 \mathrm{~cm})$ is heralded by a peak of magnetic susceptibility (Fig. 3A). Highly negative values of factor 3, i.e., higher Se, La, and Ce contents, reflect lesser dilution of minor elements by quartz and carbonate. The variation patterns of transition elements and other metals are very similar to those of unit B. As already observed for rivers (Yang et al., 2002), a strong correlation exists between grain size and lanthanide concentrations (Zhang et al., 1998; Yang et al., 2002). This geochemical change is consistent with a sand fraction in unit C smaller than that in unit B. Unit C shows some transient geochemical features (Fig. 7), true harbingers of the major changes that would profoundly affect unit D, notably an increase in sulfur and heavy metal contents.

The transition $(550-515 \mathrm{~cm}$ ) between unit $C$ and unit $D$ $(515-300 \mathrm{~cm})$ also is announced by a strong peak of magnetic susceptibility (Fig. 3A), corresponding to a strong compositional shift with a surge of the biogenic component $(F 1<0)$ due to degraded ventilation of bottom waters by eutrophication $(\mathrm{F} 2<0)$. Sulfide reduction and precipitation is attested to by a sudden twoorder-of-magnitude increase in the S/Al ratio (Fig. 6). The surge in sulfur, $\mathrm{Zn}, \mathrm{Ni}$, and Co conspicuously follows the surge in $\mathrm{Ca}, \mathrm{Pb}, \mathrm{Ag}$, $\mathrm{Cu}, \mathrm{Cd}, \mathrm{Mo}$, and $\mathrm{Cr}$ by some $30 \mathrm{~cm}$ in the core. This delay, which may have been as short as a few years and possibly was only one or two years, is visible in the plot of Fig. 7 as a pronounced negative excursion of ratios such as $\mathrm{Ca} / \mathrm{S}, \mathrm{Mo} / \mathrm{S}$, and $\mathrm{Pb} / \mathrm{S}$ between 520 and $550 \mathrm{~cm}$ depth. These characteristics together with high $\mathrm{Sr}$ abundance and the presence of fine calcareous layers (Kylander et al., 2011; Martín-Puertas et al., 2011) show that sulfide precipitation predated the development of eutrophic conditions manifested by the rise in $\mathrm{Ca}$ and was due to the sudden isolation of the harbor from ventilated waters. The trend of decreasing ratios of chalcophile elements relative to sulfur, which was perceptible already in

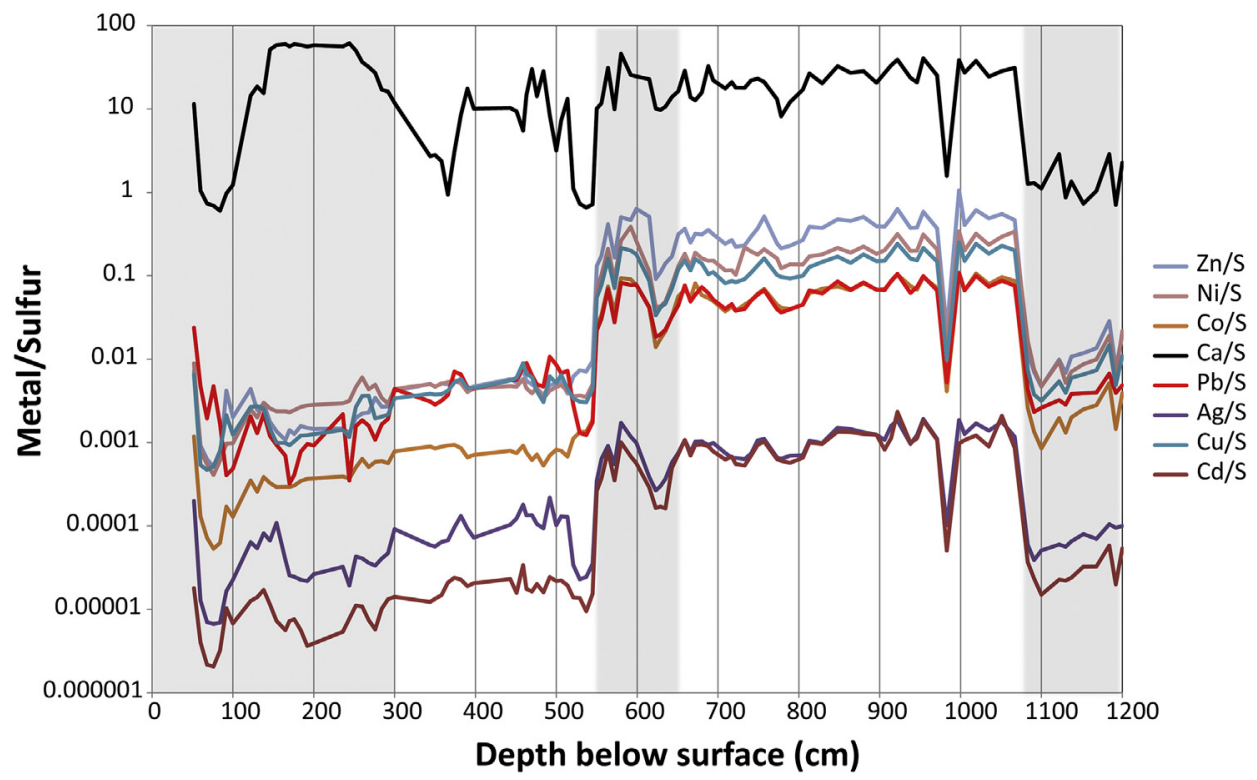

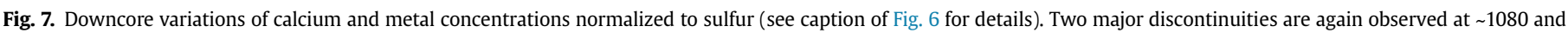

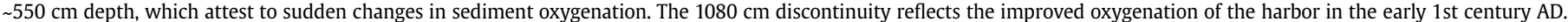

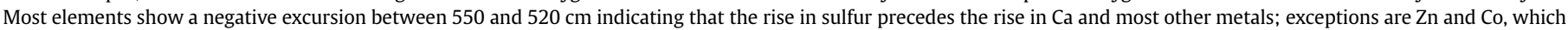
are in phase with S. Although a slow trend towards anoxia can be seen in sediments below the $550 \mathrm{~cm}$ level, the rate of ventilation is greatly reduced after this episode. 

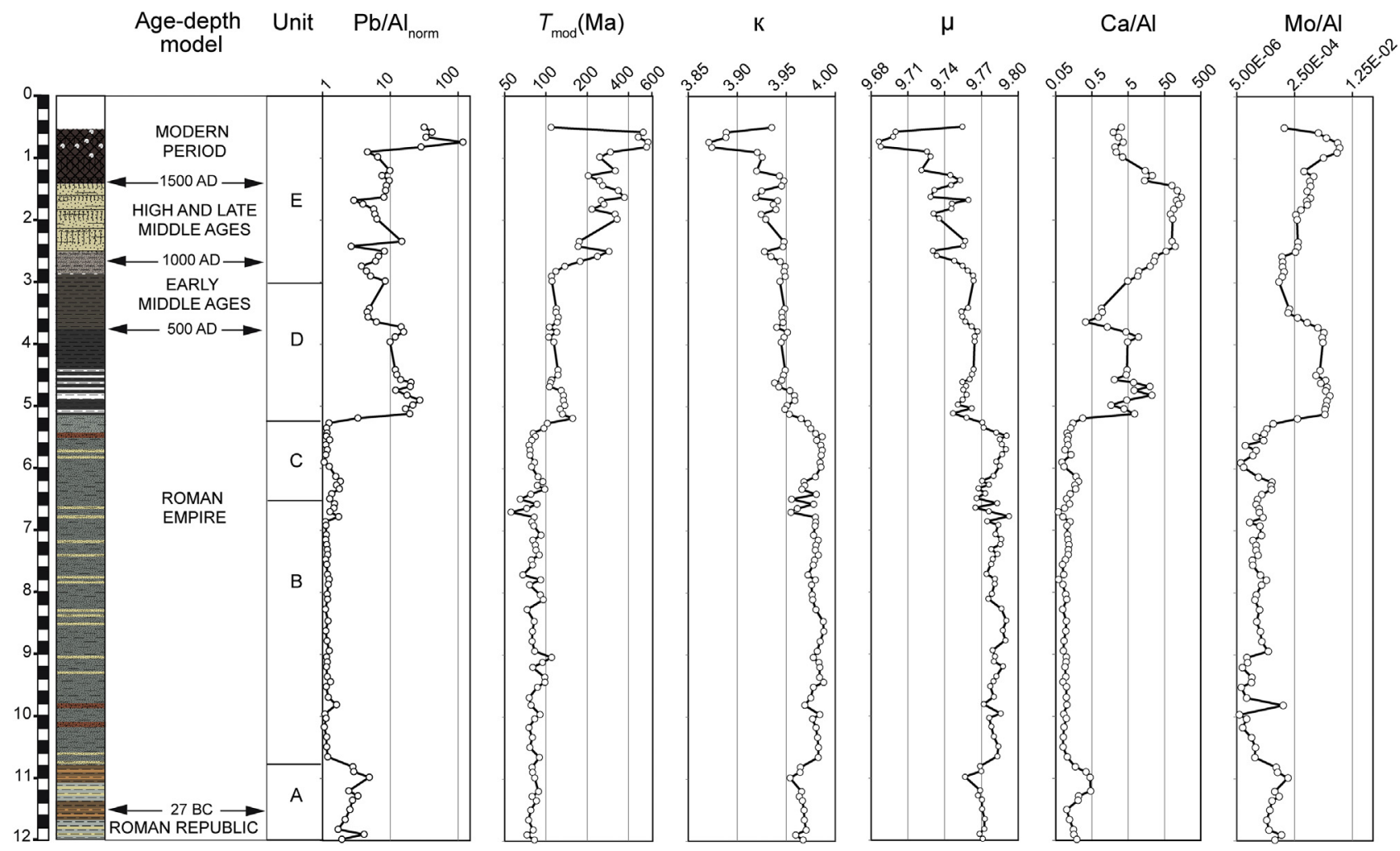

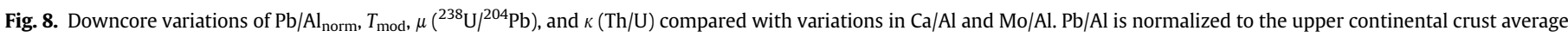

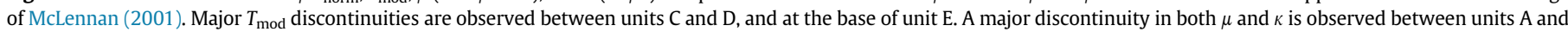
$\mathrm{B}$. The variability within unit $\mathrm{E}$ reflects an anthropogenic component of uncertain origin.

the early harbor, markedly changes at the C-D boundary, and the rate at which these ratios change significantly increases as well. Again, the correlation between $\mathrm{Cr}, \mathrm{Cu}, \mathrm{Pb}, \mathrm{Mo}$, and $\mathrm{Ag}$ (Figs. 6 and 7, S1) excesses is not in favor of selective pollution by metallurgical or any other industrial activities. The destruction of the aqueducts by the major earthquakes ravaging the city, such as the $\mathrm{AD} 17,23$, and 47 events (see discussion in Guidoboni, 1994), and the AD 64 AD cleaning credited to Barea Soranus by Tacitus (XVI,23) may have combined with the increasing silting of the harbor entrance upon westward progradation of the delta (Fig. 1) (Brückner, 2005) to modify the hydraulic regime of the harbor. The top of unit $\mathrm{D}$ records a short-lived return of better oxygenated conditions which, with the caution due the age-depth model, may correspond to the revival of the harbor by Justinian (early and mid- 6th century; Foss, 1979; Scherrer, 1995).

The age-depth model (Fig. 4) places the transition between units $\mathrm{D}$ and $\mathrm{E}(\sim 300 \mathrm{~cm})$ in the 9th century. Carbonate precipitation dominates unit $\mathrm{E}$ as it did the lower part of unit $\mathrm{D}(\mathrm{F} 1<0)$ indicating a negative water balance (Fig. 2B; Martín-Puertas et al., 2011; Delile et al., 2014b). Excesses of $\mathrm{Cr}, \mathrm{Cu}$, Mo, and $\mathrm{Ag}$ are still well correlated (Fig. 2A) and confirm the persistence of a sulfurrich, oxygen-deficient eutrophic regime, but, as shown by the positive F2 values, with oxygen deficiency being less pronounced than in the underlying unit $\mathrm{D}$. The water deficit caused conditions to evolve towards a peatland environment consistent with the considerable extension of the Cayster delta at this time (Fig. 1). The modern estuary of the Küçük Menderes is wetland dotted with alkaline lakes recharged from precipitation and local karstic springs. In late Byzantine times, the harbor may have been functional, but appears to have been increasingly cut off from the sea and the river (Kraft et al., 2011) (Fig. 1). Some of the shallow core samples show excess $\mathrm{Pb}$ of probable but uncertain anthropic origin (Fig. 8).

To sum up on environmental conditions, core EPH 276 holds the record of anoxic conditions prevailing at times in the harbor, likely compromising the control of harbor hydrodynamics by human activities. Lead isotopes are expected to shed light on the magnitude of anthropogenic contamination at the time of sediment deposition and this is what the next section will be addressing.

\subsection{Interpretation of $\mathrm{Pb}$ abundance and isotopic signals}

Here we focus on the $\mathrm{Pb}$ isotope compositions of the leached fractions only because this is where chances of observing anthropogenic input are maximum. Fig. 8 shows the $\mathrm{Pb} / \mathrm{Al}$ ratio together with the $\mathrm{Pb}$ isotope data in the form of three geochemical parameters, $T_{\text {mod }}$ (Ma $=$ million years), $\mu$, and $\kappa$. Based on these parameters and the enrichment factor of $\mathrm{Pb}$ as represented by $\mathrm{Pb} / \mathrm{Al}$ and closely tracking F2, the chronostratigraphic evolution of these four curves shows remarkable discontinuities (Fig. 2). In agreement with what was discussed above for other metals, the transition between units $A$ and B stands out clearly by a marked drop in $\mathrm{Pb} / \mathrm{Al}$. A subtle increase in $\mu$ and $\kappa$, while $T_{\text {mod }}$ remains young ( $~ 80$ Ma or Upper Cretaceous), is evidence of change in the sources of $\mathrm{Pb}$. The next discontinuity takes place between units $\mathrm{C}$ and $\mathrm{D}$. The increase in $\mathrm{Pb} / \mathrm{Al}$ and $\mathrm{Ca} / \mathrm{Al}$ is associated with older $T_{\text {mod }}(\sim 120$ Ma or Early Cretaceous) and lower values of $\mu$ and $\kappa$. The $\mathrm{Pb} / \mathrm{Al}$ ratio decreases steadily throughout unit $\mathrm{D}$ regardless of the changes in the major $\mathrm{Ca} / \mathrm{Al}$ dip at $3.8 \mathrm{~m}$ depth that we assigned above to the 6 th century. From unit D to E, most $T_{\bmod }$ values exceed $240 \mathrm{Ma}$ and the $\kappa$ values decrease below the level of previous values. The samples at the top of the core seem to be largely influenced by a modern anthropogenic component. 
The hydraulics of the harbor, notably its volume and output, may affect harbor oxygenation and thereby the metal contents of sediments. In contrast, changing $\mathrm{Pb}$ isotope compositions require changes in the relative contribution of all the sources of this metal. Lead isotopes reveal the nature and relative strengths of the following potential sources:

1. Local natural sources, which are multiple. Lead from the Cayster River comes during short-lived seasonal flood events. Seawater should be extremely poor in $\mathrm{Pb}$, while brackish water from the estuary should be Pb-depleted by iron flocculation in the mixing zone. A contribution from the runoff and from karstic springs that discharge from marble-schists and marble-alluvium contacts (Somay et al., 2008; Somay and Gemici, 2009) should also be considered.

2. Lead from the main water distribution system. Such a component may come from the underground of the springs. It can also be acquired during transit from the aqueduct masonry, which includes mortar produced from local limestones. The laminated deposits observed in some aqueducts (Passchier et al., 2011, 2013) indicate hard water with excess alkalinity, which does not favor the idea that $\mathrm{Pb}$ was leached out of these conduits. The seemingly high concentrations of chalcophile elements in the sediments, first and foremost $\mathrm{Pb}$ but also $\mathrm{Co}$ and $\mathrm{Mo}$, do not entail a pollution signal.

3. The network of aqueducts, which is unlikely to be a major $\mathrm{Pb}$ contributor. The secondary water distribution system at Ephesus is dominated by terra cotta pipes and only rarely involves small-diameter lead pipes or fistulae (Ortloff and Crouch, 2001).

4. Anthropogenic $\mathrm{Pb}$ from local workshops or ballast dropped by merchant ships. Zabehlicky (1995) writes that a lead anchor $14.2 \mathrm{~cm}$ long was found during excavations, as well as lead interpreted as ballast, which as much as hinting at a potential source of pollution, signals that the dissolution of $\mathrm{Pb}$ artifacts is an exceedingly slow process. The presence of an arsenal on the harbor site at the time of Augustus was noted by Strabo (XIV.1.24). There is no doubt that a city with the population of Ephesus at its best periods would have to rely on local metallurgy. In sediments, however, a geochemical signal of pollution is difficult to detect, and to which extent $\mathrm{Pb}$ artifacts attest to wholesale contamination of harbor sediments is not clear. The stability of $\mathrm{Pb}$ isotope compositions over long periods of time (decades, even centuries) does not bring to mind metal supply in troubled times. Even more conclusive is the observation that, except for unit $\mathrm{E}, \mathrm{Cr}, \mathrm{Cu}, \mathrm{Mo}, \mathrm{Ag}$, and $\mathrm{Cu}$ coherently track $\mathrm{Pb}$ and $\mathrm{Ca}$ : although these elements are sensitive to redox conditions, they were not involved in $\mathrm{Pb}$ metallurgy. The $\mathrm{Pb} / \mathrm{Ag}$ ratio remains remarkably stable, while the record of $\mathrm{Ni}$ and $\mathrm{Co}$, for which extractive metallurgy was unknown at the time and which additionally are not found in the same ores as $\mathrm{Pb}$, also follow the $\mathrm{Pb}$ record with depth. The lesser impact of anthropogenic $\mathrm{Pb}$ pollution at Ephesus relative to Portus (Delile et al., 2014a) directly reflects that the urban water distribution systems used different materials, terra cotta for the former (Ortloff and Crouch, 2001) and lead fistulæ for the latter.

The Cretaceous model ages of $80 \mathrm{Ma}$ and $120 \mathrm{Ma}$ observed in the lower part of the core are consistent with those of the carbonate hills surrounding Ephesus and may simply register $\mathrm{Pb}$ from the water distribution system (natural springs or conduits). This interpretation is supported by the similar $\mathrm{Pb}$ isotope compositions of leachate-residue pairs (Table S2). The residues of the samples with $T_{\text {mod }}$ values $>200$ Ma have not been analyzed, but these ages are consistent with the age of the Paleozoic and Triassic crystalline basement of the Menderes Massif (Vetters, 1989; Bozkurt, 2007; Çakmakoğlu, 2007; Gürer et al., 2009) (see maps in the supplementary material of Delile et al., 2014a).
The appearance of old $T_{\text {mod }}$ values shortly after the beginning of unit $\mathrm{E}$, which have not been observed at earlier times, coincides with the onset of carbonate sedimentation (up to $45 \mathrm{wt} . \% \mathrm{CaO}$ ). Runoff and karstic springs more or less contaminated by seawater (Somay et al., 2008; Somay and Gemici, 2009) are therefore left as the main steady sources of water in the ancient port, which since has become the modern Lake Kocagöz. Two competing interpretations are left: (1) while ancient aqueducts were bringing in Cretaceous $\mathrm{Pb}$, runoff and karstic springs now bring in Paleozoic $\mathrm{Pb}$; or (2) old $T_{\text {mod }}$ values reflect some anthropic influence of poorly constrained origin. The younger samples with $T_{\text {mod }}$ values $>200 \mathrm{Ma}$ may represent sources in the Menderes region, but $\mathrm{Pb}$ from Thrace, or even from western Europe, cannot be excluded.

Historical evidence in favor of Ephesus hosting significant industrial activity in the 11th and 12th centuries (Foss, 1979, pp. 120-123), however, is faint. Foss (1979, p. 113) further argues that from the 8th century onwards the harbor district was literally abandoned. The center of town moved to the hill of Ayasuluk, while new ports, such as Scalanova (ancient Phygela) built on the site of modern Kuşadası, gradually took over the silted in harbor of Ephesus.

Nevertheless, from the middle of the 9th to the 10th century, the victories of the Byzantines against the Arabs in Asia Minor enabled Ephesus to regain a preeminent position in the Empire (Foss, 1979). A phase of economic development would be consistent with the influx of Hercynian $\mathrm{Pb}$ into the most recent harbor deposits. The 10th century medieval economic revolution in Europe favored the development of trade between Europe and the Orient. West or north European sources of $\mathrm{Pb}$ cannot be excluded for that period.

\section{Concluding remarks}

Major changes in the lithology, grain-size distribution, major and trace element chemistry, and $\mathrm{Pb}$ isotope compositions of the harbor sediments at Ephesus reflect the history of the water distribution system of this port, notably in response to the increasing and declining needs of a population inhabiting a city that at several points in history was one of the largest of the Eastern Mediterranean. Throughout its history, the Ephesus port was affected by major disruptive events in the form of earthquakes and invasions, both of which were particularly effective at destroying aqueducts.

Progressive silting in of the harbor responded to the westward migration of the coastline and to human maintenance aimed at keeping the harbor functional. A single major disruptive event located at $550 \mathrm{~cm}$ core depth and heralding a two-order-of-magnitude drop in sedimentation rate and the development of anoxia in the harbor is clearly visible in the major and trace element record. Although this event may have unidentified military or seismic causes, we favor a durable displacement of the river course, which starved the harbor from further silt input. Overall, despite the presence of metallic artifacts in the harbor, the record of metal concentrations, in particular the $\mathrm{Pb}$ isotope record, suggests that pollution of the harbor was subdued relative to other inputs, notably those of aqueducts, except near the time of harbor abandonment (unit E).

Dating and identifying the seemingly key event located in the present sediment core at $550 \mathrm{~cm}$ depth, as well as in other cores from the same basin, is a new and major challenge. This event conspicuously marks the end of the dynamic regime controlling the harbor water during all of the Roman Empire and clearly represents a major disturbance in the history of life in Ephesus.

\section{Acknowledgments}

We thank the Austrian Archaeological Institute (ÖAI, Wien), especially its director Sabine Ladstätter, for the possibility to work in Ephesus. The Turkish authorities kindly granted the research 
permits. The Young Scientist Program of the Agence Nationale de la Recherche (CNRS) (ANR 2011 JSH3 002 01) and the Roman Mediterranean Ports program (ERC) (102705) provided financial and logistic support. Two further samples were ${ }^{14} \mathrm{C}$ dated at the Center for Applied Isotope Studies, University of Georgia at Athens, USA. We also acknowledge support of the ARTEMIS program for carrying out the SMA radiocarbon dating. We further thank the Institut National des Sciences de l'Univers for supporting the analytical facility at ENS Lyon. A. Wilson kindly provided his personal Mediterranean shipwreck database. Melis Somay gave advice on the karstic sources around Ephesus. Two generous and insightful, yet anonymous, reviews helped improve the manuscript.

Appendix A. Matlab code for $T_{\bmod }, \mu$, and $\kappa$ calculations

The input data should be provided as an Excel file input.xlsx made of three columns, holding ${ }^{206} \mathrm{~Pb} /{ }^{204} \mathrm{~Pb}$, ${ }^{207} \mathrm{~Pb} /{ }^{204} \mathrm{~Pb}$, and ${ }^{208} \mathrm{~Pb} /{ }^{204} \mathrm{~Pb}$.

$\%$ Matlab code for model age calculations (Francis Albarede)

$\%$

$\mathrm{A}=\mathrm{xlsread}($ 'input.xlsx',1);

$\mathrm{m}=\operatorname{size}(\mathrm{A}, 1) ; \%$ find $\mathrm{m}$ the number of samples

$\%$ decay constants

$18=0.155125 ; 15=0.98485 ; 12=0.049475$;

$\%$ common Pb parameters from Albarede and Juteau (1984)

xstar $=18.7500 ; y$ star $=15.63 ;$ zstar $=38.83 ;$ kappastar $=3.90 ;$ mustar $=9.66$;

$\%$ Initialize

$\mathrm{FF}=\mathrm{zeros}(\mathrm{m}, 1) ; \mathrm{mu}=\mathrm{zeros}(\mathrm{m}, 1) ; \mathrm{dmu}=\mathrm{zeros}(\mathrm{m}, 1) ; \operatorname{kappa}=\mathrm{zeros}(\mathrm{m}, 1) ; \mathrm{dkappa}=\mathrm{zeros}(\mathrm{m}, 1) ; \operatorname{Tmod}=\mathrm{zeros}(\mathrm{m}, 1) ; \operatorname{Tinit}=$ 1 ;

T0=3.8; \% Beginning stage 2 (Ga), see Stacey and Kramers (1975)

options $=$ optimset('Display','off');

for $\mathrm{i}=1: \mathrm{m} \%$ loop through all samples

$\mathrm{x}=\mathrm{A}(\mathrm{i}, 1) ; \mathrm{y}=\mathrm{A}(\mathrm{i}, 2) ; \mathrm{z}=\mathrm{A}(\mathrm{i}, 3)$;

myf=@(T)TmPb(T,T0,x,y);

[Tmod(i), FF(i),exitflag(i,1)]=fsolve(myf,Tinit,options); \% use Matlab fsolve with function $\mathrm{TmPb}$

$\mathrm{T} 1=\mathrm{Tmod}(\mathrm{i})$;

$\mathrm{dmu}(\mathrm{i})=(\mathrm{x}-\mathrm{xstar}+\operatorname{mustar} *(\exp (18 * \mathrm{~T} 1)-1)) /(\exp (18 * \mathrm{~T} 0)-\exp (18 * \mathrm{~T} 1))$;

$\mathrm{mu}(\mathrm{i})=$ mustar $+\mathrm{dmu}(\mathrm{i})$;

dkappa(i) $=\left(\mathrm{z}-\mathrm{zstar}+\right.$ mustar*kappastar* $(\exp (12 * \mathrm{~T} 1)-1)-\operatorname{kappastar}{ }^{*} \mathrm{dmu}(\mathrm{i}) *(\exp (12 * \mathrm{~T} 0)-$

$\exp (12 * \mathrm{~T} 1))) /(\exp (12 * \mathrm{~T} 0)-\exp (12 * \mathrm{~T} 1)) / \mathrm{mu}(\mathrm{i})$;

kappa(i) $=$ kappastar+dkappa(i);

end

$\mathrm{B}=[\mathrm{A}, 1000 *$ Tmod,mu,kappa,FF, exitflag]

$\% \mathrm{~B}$ holds columnwise the original ratios (A), the model age (in Ma), mu, kappa, the

$\%$ exit value of the function to solve (should be less than 1e-9) and an

$\%$ exit parameter ( 1 expected)

function $\mathrm{F}=\mathrm{TmPb}(\mathrm{T}, \mathrm{T} 0, \mathrm{x}, \mathrm{y})$

mustar $=9.66$;

xstar $=18.7500 ; y s t a r=15.63 ; \% A J$

$18=0.155125 ; 15=0.98485$;

$\mathrm{p} 0=(\exp (15 * \mathrm{~T} 0)-\exp (15 * \mathrm{~T})) /(\exp (18 * \mathrm{~T} 0)-\exp (18 * \mathrm{~T})) / 137.8 ;$

$\mathrm{p} 1=(\exp (15 * \mathrm{~T})-1) /(\exp (18 * \mathrm{~T})-1) / 137.8$;

$\%$

if $\mathrm{x} \sim=\mathrm{xstar} \%$ Eq. 12 in Albarede et al. (2012)

$\mathrm{F}=(\mathrm{y}-\mathrm{ystar}) /(\mathrm{x}-\mathrm{xstar})-\mathrm{p} 0-\mathrm{mustar} *(\exp (18 * \mathrm{~T})-1) *(\mathrm{p} 0-\mathrm{p} 1) /(\mathrm{x}-\mathrm{xstar})$;

else

$\mathrm{F}=(\mathrm{y}$-ystar $)-\operatorname{mustar} *(\exp (18 * \mathrm{~T})-1) *(\mathrm{p} 0-\mathrm{p} 1)$; end

end 
Appendix. BSupplementary data

Supplementary data related to this article can be found at http:// dx.doi.org/10.1016/j.jas.2014.10.002.

\section{References}

Albarède, F., 1995. Introduction to Geochemical Modeling. Cambridge University Press, Cambridge, p. 543.

Albarède, F., Desaulty, A.-M., Blichert-Toft, J., 2012. A geological perspective on the use of $\mathrm{Pb}$ isotopes in Archaeometry. Archaeometry 54, 853-867.

Blaauw, M., 2010. Methods and code for "classical" age-modelling of radiocarbon sequences. Quat. Geochronol. 5, 512-518.

Bozkurt, E., 2007. Extensional v. contractional origin for the southern Menderes shear zone, SW Turkey: tectonic and metamorphic implications. Geol. Mag. 144, $191-210$.

Bravard, J.-P., Peiry, J.-L., 1999. The CM pattern as a tool for the classification of alluvial suites and floodplains along the river continuum. In: Marrott, S.B. Alexander, J. (Eds.), Floodplains: Interdisciplinary Approaches. Geological Society Special Publication, London, pp. 259-268.

Bravard, J.-P., Goichot, M., Tronchère, H., 2014. An assessment of sediment-transport processes in the Lower Mekong River based on deposit grain sizes, the CM technique and flow-energy data. Geomorphology 207, 174-189.

Brown, A.G., 1997. Alluvial Geoarchaeology: Floodplain Archaeology and Environmental Change. Cambridge University Press, p. 377.

Brückner, H., 1997. Geoarchäologische Forschungen in derWesttürkei: das Beispiel Ephesus. Passau. Schr. Geogr. 15, 39-51.

Brückner, H., 2005. Holocene shoreline displacements and their consequences for human societies: the example of Ephesus in western Turkey. Z. Geomorphol. Suppl. 137, 11-22.

Cakmakoglu, A., 2007. Pre - neogene tectonostratigraphy of Dilek Peninsula and the area surrounding Söke and Selçu. Bull. Miner. Res. Explor. 135, 1-17.

Delile, H., Blichert-Toft, J., Goiran, J.-P., Keay, S., Albarède, F., 2014a. Lead in Ancient Rome's City Waters, vol. 111. PNAS.

Delile, H., Mazzini, I., Blichert-Toft, J., Goiran, J.-P., Arnaud-Godet, F., Salomon, F. Albarède, F., 2014b. Geochemical investigation of a sediment core from the Trajan basin at Portus, the harbor of ancient Rome. Quat. Sci. Rev. 87, 34-45.

Eisele, J., Abouchami, W., Galer, S.J.G., Hofmann, A.W., 2003. The 320 kyr Pb isotope evolution of Mauna Kea lavas recorded in the HSDP-2 drill core. Geochem. Geophys. Geosyst. 4, 8710.

Foss, C., 1979. Ephesus After Antiquity: a Late Antique, Byzantine and Turkish City. Cambridge University Press.

Guidoboni, E., 1994. Catalogue of Ancient Earthquakes in the Mediterranean Area up to the 10th Century. Istituto nazionale di geofisica, Rome, Italie.

Gürer, Ö.F., Sarica-Filoreau, N., Özburan, M., Sangu, E., Doğan, B., 2009. Progressive development of the Büyük Menderes Graben based on new data, western Turkey. Geol. Mag. 146, 652-673.

Hong, S., Candelone, J.-P., Patterson, C.C., Boutron, C.F., 1994. Greenland ice evidence of hemispheric lead pollution two millennia ago by greek and roman civilizations. Science 265, 1841-1843.

Kirbihler, F., 2013. Les nauclères, l'entretien du port et l'implication des gens de mer dans la vie civique éphésienne. In: E, Médiévale Et Moderne, Histoire. Presse Universitaires de Rennes, Rennes, pp. 111-126.

Kraft, J.C., Brückner, H., Kayan, İ., 1999. Palaeogeographies of Ancient Coastal Environments in the Environs of the Feigengarten Excavation and the "Via(e Sacra(e)" to the Artemision at Ephesus. In: Scherrer, P., et al. (Eds.), Steine und Wege, Festschrift für Dieter Knibbe zum 65. Geburtstag. Österreichisches Archäologisches Institut, pp. 91-100. Sonderschriften.

Kraft, J.C., Kayan, I., Brückner, H., Rapp, G., 2000. A geological analysis of ancient landscapes and the harbors of Ephesus and the Artemision in Anatolia. In: Jahreshefte Des Österreichischen Archäologischen Institutes in Wien, pp. 175-233.

Kraft, J.C., Kayan, I., Brückner, H., 2001. The geological and paleogeographical environs of the Artemision. In: Muss, U. (Ed.), Der Kosmos Der Artemis Von Ephesos, Sonderschriften. Österreichisches Archäologisches Institut, Vienna, pp. 123-133.

Kraft, J.C., Brückner, H., Kayan, İ., Engelmann, H., 2007. The geographies of ancient Ephesus and the Artemision in Anatolia. Geoarchaeology 22, 121-149.

Kraft, J.C., Rapp, G., Brükner, H., Kayan, I., 2011. Results of the Struggle at Ancient Ephesus: Natural Processes 1, Human Intervention 0. Geological Society, London, pp. 27-36. Special Publications 352.

Kylander, M.E., Ampel, L., Wohlfarth, B., Veres, D., 2011. High-resolution X-ray fluorescence core scanning analysis of Les Echets (France) sedimentary sequence: new insights from chemical proxies. J. Quat. Sci. 26, 109-117.

Lambeck, K., Purcell, A., 2005. Sea-level change in the Mediterranean Sea since the LGM: model predictions for tectonically stable areas. Quat. Sci. Rev. 24 1969-1988.

Le Roux, G., Veron, A., Morhange, C., 2003. Geochemical evidences of early anthropogenic activity in harbour sediments from Sidon. Archaeol. Hist. Leban. 18, 115-119.

Le Roux, G., Véron, A., Morhange, C., 2005. Lead pollution in the ancient harbours of Marseilles. Méditerranée 31-35.
Martín-Puertas, C., Valero-Garcés, B.L., Mata, M.P., Moreno, A., Giralt, S., MartínezRuiz, F., Jiménez-Espejo, F., 2011. Geochemical processes in a Mediterranean Lake: a high-resolution study of the last 4,000 years in Zoñar Lake, southern Spain. J. Paleolimnol. 46, 405-421.

McLennan, S.M., 2001. Relationships between the trace element composition of sedimentary rocks and upper continental crust. Geochem. Geophys. Geosyst. 2 , 24.

Ortloff, C.R., Crouch, D.P., 2001. The urban water Supply and distribution system of the Ionian City of Ephesos in the Roman Imperial Period. J. Archaeol. Sci. 28, 843-860.

Passchier, C.W., Wiplinger, G., Güngör, T., Kessener, P., Sürmelihindi, G., 2013. Normal fault displacement dislocating a Roman aqueduct of Ephesos, western Turkey. Terra Nova 25, 292-297.

Passchier, C.W., Wiplinger, G., Sürmelihindi, G., Kessener, P., Güngör, T., 2011. Roman aqueducts as indicators of historically active faults in the mediterranean basin. In: Presented at the 2nd INQUA-IGCP-567 International Workshop on Active Tectonics, Earthquake Geology, Archaeology and Engineering, Corinth, Greece, pp. 186-189.

Pavlopoulos, K., Kapsimalis, V., Theodorakopoulou, K., Panagiotopoulos, I.P., 2012. Vertical displacement trends in the Aegean coastal zone (NE Mediterranean) during the Holocene assessed by geo-archaeological data. Holocene 22, $717-728$.

Reimer, P.J., Baillie, M.G.L., Bard, E., Bayliss, A., Beck, J.W., Blackwell, P.G., Ramsey, C.B., Buck, C.E., Burr, G.S., Edwards, R.L., Friedrich, M., Grootes, P.M., Guilderson, T.P., Hajdas, I., Heaton, T.J., Hogg, A.G., Hughen, K.A., Kaiser, K.F., Kromer, B., McCormac, F.G., Manning, S.W., Reimer, R.W., Richards, D.A. Southon, J.R., Talamo, S., Turney, C.S.M., van der Plicht, J., Weyhenmeyer, C.E., 2009. IntCal09 and Marine09 radiocarbon age calibration curves, 0-50,000 years cal BP. Radiocarbon 51, 1111-1150.

Rojay, B., Toprak, V., Demirci, C., Süzen, L., 2005. Plio-Quaternary evolution of the Küçük Menderes Graben Southwestern Anatolia, Turkey. Geodin. Acta 18, $317-331$.

Rudnick, R.L., Gao, S., 2003. Composition of the Continental Crust. Treatise Geochem. 3, 1-64.

Scherrer, P., 1995. The city of Ephesos: from the roman period to late antiquity. In: Koester, Helmut (Ed.), Ephesos Metropolis of Asia: an Interdisciplinary Approach to its Archaeology, Religion, and Culture, Harvard Theological Studies. Trinity Press International, pp. 1-25.

Somay, A.M., Gemici, Ü., Filiz, S., 2008. Hydrogeochemical investigation of Küçük Menderes River coastal wetland, Selçuk-Izmir, Turkey. Environ. Geol. 55, $149-164$.

Somay, A.M., Gemici, Ü., 2009. Assessment of the salinization process at the Coastal Area with Hydrogeochemical tools and Geographical Information Systems (GIS): Selçuk Plain, Izmir, Turkey. Water Air Soil Pollut. 201, 55-74.

Stanley, J.-D., Carlson, R.W., Van Beek, G., Jorstad, T.F., Landau, E.A., 2007. Alexandria, Egypt, before Alexander the Great: a multidisciplinary approach yields rich discoveries. GSA Today 17, 4-10.

Stock, F., Pint, A., Horejs, B., Ladstätter, S., Brückner, H., 2013. In search of the harbours: new evidence of Late Roman and Byzantine harbours of Ephesus. Quat. Int. 312, 57-69.

Stock, F., Kerschner, M., Kraft, J.C., Pint, A., Frenzel, P., Brückner, H., 2014. The palaeogeographies of Ephesos (Turkey), its harbours and the Artemision - a geoarchaeological reconstruction for the timespan 1500-300 BC. Z. Geomorphol. 58 (Suppl. 2), 33-66.

Strabo, 1924. Geography. Loeb Classical Library, Cambridge.

Tacitus, 2009. Annals. http://classics.mit.edu/Tacitus/annals.html.

Vannucci, G., Pondrelli, S., Argnani, A., Morelli, A., Gasperini, P., Boschi, E., 2004. An atlas of Mediterranean seismicity. Ann. Geophys. 47, 247-306.

Véron, A.J., Flaux, C., Marriner, N., Poirier, A., Rigaud, S., Morhange, C., Empereur, J.Y., 2013. A 6000-year geochemical record of human activities from Alexandria (Egypt). Quat. Sci. Rev. 81, 138-147.

Véron, A., Goiran, J.P., Morhange, C., Marriner, N., Empereur, J.Y., 2006. Pollutant lead reveals the pre-Hellenistic occupation and ancient growth of Alexandria, Egypt. Geophys. Res. Lett. 33, 1-4.

Vetters, W., 1989. Geologische Übersichtskarte der Umgebung von Ephesus.

Vliegenthart, F.J.L., Sargin, A.H., Gorkmen, A., Dogdu, M.S., 2007. A new approach for groundwater management in Turkey. In: International Congress on River Basin Management, pp. 64-79.

Wiplinger, G., 2013. Der Değirmendere Aquädukt von Ephesos und seine Zukunft (Wissenschaftlicher Jahresbericht des Österreichischen Archäologischen Instituts No. 24), Babesch. Annual Papers on Mediterranean Archaeoly. Österreichisches Archäologisches Institut, Wien.

Yang, S.Y., Jung, H.S., Choi, M.S., Li, C.X., 2002. The rare earth element compositions of the Changjiang (Yangtze) and Huanghe (Yellow) river sediments. Earth Planet. Sci. Lett. 201, 407-419.

Zabehlicky, H., 1995. Preliminary views of the Ephesian harbor. In: Koester, H. (Ed.) Ephesos - Metropolis of Asia. An Interdisciplinary Approach to its Archaeology, Religion, and Culture, Harvard Theological Studies. Massachusetts, Cambridge, pp. 201-216.

Zhang, C., Wang, L., Zhang, S., Li, X., 1998. Geochemistry of rare earth elements in the mainstream of the Yangtze River, China. Appl. Geochem. 13, 451-462. 